\title{
Epigenetic Mechanisms Involved in Huntington's Disease Pathogenesis
}

\author{
Kelly E. Glajch and Ghazaleh Sadri-Vakili* \\ MassGeneral Institute for Neurodegenerative Disease, Massachusetts General Hospital, Boston, MA, USA
}

\begin{abstract}
Transcriptional dysregulation is an early event and may be an important pathological mechanism in Huntington's disease (HD). However, the exact process that leads to alterations in gene expression in HD is not clear. One potential mechanism underlying transcriptional abnormalities in HD may be epigenetic alterations which regulate gene expression without changing the DNA sequence. Previous work has demonstrated that epigenetic marks, such as DNA methylation and post-translational modifications of histone proteins, are significantly altered in HD cellular and animal models as well as HD patients. Furthermore, studies have shown a therapeutic role for histone deacetylase (HDAC) inhibitors in numerous HD models. Here, we review a range of studies describing epigenetic changes in HD as well as several potential therapeutics that target aberrant epigenetic alterations in HD.
\end{abstract}

Keywords: Epigenetics, Huntington's disease, DNA methylation, histone modifications, huntingtin, transcription

\section{INTRODUCTION}

\section{Huntington's disease}

Huntington's disease (HD) is an autosomal dominant neurological disease that typically begins in young adult life and is invariably fatal [1]. Patients with HD initially demonstrate personality changes and small involuntary movements. As the disease progresses, the movement disorder is more pronounced, and cognitive issues and psychiatric disturbances occur [2]. Weight loss is also a common feature in HD, highlighting the existence of a generalized metabolic deficit in patients [3]. Pathologically, HD is characterized by cerebral atrophy. Although HD affects a number of brain regions such as the cortex, thalamus, and subthalamic nucleus, the striatum is the most severely affected region $[4,5]$.

HD is caused by a mutation in the huntingtin gene located on chromosome 4 that encodes the protein

\footnotetext{
*Correspondence to: Ghazaleh Sadri-Vakili, Ph.D., MassGeneral Institute for Neurodegenerative Disease, Massachusetts General Hospital, 114 16th Street, Charlestown, MA 02129-4404, USA. Tel.: +1 617724 1487; Fax: +1 617724 1480; E-mail: gsadrivakili@mgh.harvard.edu.
}

huntingtin (Htt) [6]. This mutation is an expansion of the cytosine-adenine-guanine (CAG) trinucleotide repeat within exon 1 , which is translated into a polyglutamine (polyQ) moiety in the $\mathrm{Htt}$ protein. While normal individuals have 7-34 CAG repeats, in HD patients the repeat length is expanded. Typically, repeat lengths of $>40$ glutamines lead to HD, and repeat lengths of $>100$ glutamines cause juvenile onset disease [7].

Even though the genetic mutation was discovered in 1993, the mechanism by which mutant Htt causes neuronal dysfunction is not yet unclear. However, a number of pathogenic mechanisms including transcriptional dysregulation [8-11], excitotoxicity [12], mitochondrial dysfunction [13-15], caspase activation and apoptotic cell death [16-19], and autophagy, among others, have been implicated in HD pathogenesis.

\section{Transcriptional dysregulation}

One key mechanism underlying HD pathogenesis is transcriptional dysregulation [8-11]. Aberrant transcriptional alterations occur early in HD and have been demonstrated in patients as well as multiple cellular and animal models of HD [8, 20, 21]. Specifically, HD patients as well as transgenic and knockin mouse 
models exhibit alterations in specific genes at the level of mRNA expression [8, 9, 22-24]. Previous studies in mouse models have shown changes in neurotransmitter receptor mRNA and protein levels that occur before the phenotypical disease onset $[9,21,23,25,26]$. These findings are consistent with positron emission tomography (PET) studies showing a decrease in dopamine D1 and D2 receptors in gene-positive but clinically asymptomatic HD patients [22, 27]. Thus, neuronal dysfunction appears to precede neurological symptoms in HD. Microarray studies using brain tissue samples from the R6/2 transgenic mouse model $[21,25]$ illustrated that mRNA levels are altered for genes involved in neurotransmitter signaling, calcium metabolism, and transcriptional processes [28-31]. Most of these transcripts were decreased and a larger number of genes were decreased in symptomatic mice compared to presymptomatic mice, suggesting a progressive effect. Following these initial studies, microarray analyses demonstrated mRNA changes in several other mouse and cellular HD models [8, 24]. Overall these findings agree with genome-wide studies from human brain tissue samples [32] and to a lesser degree with studies analyzing human blood samples [33]. These findings show that a large number of genes are altered in symptomatic HD patients and these results are recapitulated in HD animal models. Taken together, these findings suggest that transcriptional dysregulation is an important process in HD pathogenesis. However, the mechanisms that lead to selective alterations in gene expression are not yet clear.

Mutant Htt (mHtt), containing a polyQ expansion, interacts with numerous transcription factors such as CREB-binding protein (CBP) [10, 34], TATAbinding protein (TBP) [35], p53 [36], Sp1 [37] and nuclear factor $\kappa$ light-chain-enhancer of activated B cells $(\mathrm{NF}-\kappa \mathrm{B})$ [38]. These results led to the initial hypothesis that $\mathrm{mHtt}$ nuclear aggregates may cause transcriptional dysregulation by sequestering transcription factors. However, our previous findings in the R6/2 model demonstrated that there was no difference in transcript levels between neurons containing intranuclear inclusions and those lacking inclusions [39]. In addition to its interaction with transcription factors, Htt is cleaved by caspases yielding fragments that enter the nucleus and form nuclear aggregates, thereby potentially disrupting transcription [40]. Loss of wildtype $\mathrm{Htt}$ expression also promotes nuclear translocation of the repressor element-1 silencing transcription factor/neuron-restrictive silencer factor (REST/NRSF), which is proposed to alter transcription of selective gene targets [41]. Furthermore, expanded
polyQ repeats in the amino terminus of the Htt protein produce structural similarities to known transcription factors [42, 43] that may enhance its interactions with other nuclear proteins. Finally, Htt itself may directly bind to DNA [44] thus altering transcription. While these are all viable processes whereby $\mathrm{mHtt}$ can alter transcription, the exact mechanisms that lead to changes in gene expression in HD are not fully understood.

\section{Epigenetics}

Recent pioneering work in the field provides strong evidence that epigenetic mechanisms contribute to transcriptional dysregulation in HD. Epigenetics includes heritable and stable alterations in gene expression that occur without changing the DNA sequence [45-47]. The epigenetic mechanisms involved in regulating gene expression are complex and numerous. These modifications include alterations in the 3D structure of chromatin, chemical modifications of DNA (methylation and hydroxymethylation), post-translational modification of histones (acetylation, methylation, ubiquitylation, phosphorylation, SUMOylation, ADP ribosylation, etc.), and interactions of non-coding RNAs with chromatin [48, 49]. Alterations in the epigenome are relevant for neuronal loss and dysfunction. Therefore, novel treatment strategies for neurodegenerative diseases are focused on targeting the epigenome. In this review we will discuss the epigenetic alterations to DNA and histones that occur in patients as well as in cellular and animal models of HD.

\section{Altered epigenetics in Huntington's disease}

\section{DNA methylation}

DNA methylation occurs via the action of DNA methyltransferases (DNMTs) that add methyl groups to the $\mathrm{C} 5$ position of cytosine which predominantly resides in cytosine-guanine dinucleotide $(\mathrm{CpG})$ regions in the genome [50]. This process creates 5methylcytosines $(5 \mathrm{mCs})$ and can be followed by an additional step of $5 \mathrm{mC}$ oxidization to yield hydroxymethylcytosines (5hmCs) [51]. To simplify, within promoter regions, $5 \mathrm{mC}$ is associated with transcriptional repression, whereas $5 \mathrm{hmC}$ is associated with transcriptional activation [52, 53]. Methylation of $\mathrm{CpG}$ islands hinders transcription factor binding to DNA sequences via the recruitment of co-repressor complexes [54]. These methylated DNA regions are bound by methyl-binding domain-containing proteins, 
such as methyl CpG-binding protein 2 (MeCP2), which recruit co-repressors like histone deacetylases (HDACs) and methyltransferases to gene promoters. $\mathrm{CpG}$ methylation was originally thought to cause gene repression, however, it is now understood to be a dynamic process that can either promote or inhibit gene expression [50]. DNA methylation is critical for imprinting, $\mathrm{X}$ chromosome inactivation, and cell differentiation. In addition, it can be modified at specific loci in germ cells through exposure to environmental factors [55, 56].

For years it was believed that DNA methylation was a stable epigenetic mark involved in development. However, it has recently become clear that DNA methylation may be influenced by neuronal activity [57-59] and selectively altered in disease states [60, 61]. Thus, $\mathrm{CpG}$ methylation in HD was examined for brain derived neurotrophic factor (BDNF; $B d n f$ ) and adenosine $\mathrm{A} 2 \mathrm{~A}$ receptor $\left(\mathrm{A}_{2} \mathrm{~A} ;\right.$ Adora $\left.2 a\right)$, two genes with decreased expression in patients and several HD models [62]. While examination of single CpG dinucleotides of the $B d n f$ gene revealed little effect of $\mathrm{mHtt}$ expression in the R6/1 hippocampus [63], 5hmC levels were decreased at the 5'-end of the Adora $2 a$ gene in both human and murine striata [64]. Together these findings demonstrate that alterations in the Bdnf and Adora $2 a$ genes are not due to changes in $5 \mathrm{mC}$ alone.

While the analysis of DNA methylation at the single gene level has not revealed significant alterations, genome-wide studies have been more informative. Modified bisulfite sequencing with single base pair resolution was employed to measure DNA methylation in the STHdh cellular model of HD [65]. The results from this study demonstrated that there was a bias towards hypomethylation associated with CpG-poor regions in the mHtt expressing STHdh $h^{111 / 111}$ compared to control STHdh $h^{7 / 7}$ cells. However, changes at CpG-rich regions, typically associated with transcription start sites, were inversely related to alterations in transcription. Further analysis of the $\mathrm{CpG}$-poor regions demonstrated a negative correlation between transcription factor binding and DNA methylation in $\mathrm{STH} H h^{111 / 111}$ relative to $\mathrm{STH} H h^{7 / 7}$ cells [65]. In another study, global levels of $5 \mathrm{hmC}$ were reduced in the striatum and cortex of presymptomatic YAC128 mice [66]. Importantly, the genomic distribution of $5 \mathrm{hmC}$ levels confirmed hypomethylation at several key loci, although hypermethylation was also detected to a lesser extent. Despite a positive correlation between the presence of differential $5 \mathrm{hmC}$ regions and gene expression, the subset of genes examined was too small to define the precise contribution of $5 \mathrm{hmC}$ deficits in HD. Therefore more extensive analysis is still required in order to better understand the role of $5 \mathrm{hmC}$ in HD. Another study demonstrated that 7-methylguanine $(7 \mathrm{mG})$, a newly discovered DNA modification, was reduced in nuclear protein fractions from HD mouse models and in motor cortex from HD patients [67], suggesting that $7 \mathrm{mG}$ modifications may also be relevant to HD pathology. Though these findings demonstrate that DNA methylation changes may be directly linked to changes in gene expression in HD, further comprehensive and genome-wide analyses are required to unveil their precise role in HD pathogenesis.

Despite these findings, caution should generally be employed when interpreting DNA methylation studies in neurons since most reports regarding DNA methylation have focused on proliferative cells. While DNA methylation studies typically concentrate on $\mathrm{CpG}$ methylation, non-CpG methylation is prominent in neuronal tissue [53, 68, 69]. In addition, the brain has the highest $5 \mathrm{hmC}$ levels in the body [70-72]. Therefore, while the parallel reductions in gene expression in $\mathrm{HD}$ may be due to decreases in $5 \mathrm{hmC}$, this could also be due to increased $5 \mathrm{mC}$ levels under baseline conditions. Finally, as new DNA modifications such as $7 \mathrm{mG}$ are identified, deciphering the role of each alteration in the pathophysiology of disease becomes more complicated.

The effects of $\mathrm{mHtt}$ are not limited to alterations in DNA methylation or DNMTs since changes in $\mathrm{MeCP} 2$ interactions might also contribute to pathogenesis. A recent study by our group demonstrated that $\mathrm{Htt}$ directly interacts with $\mathrm{MeCP} 2$ in mouse and cellular models of HD [73] (Fig. 1). Our results also demonstrated that Htt-MeCP2 interactions were enhanced in the presence of the expanded polyglutamine (polyQ) tract and were stronger in the nucleus compared to the cytoplasm [73]. In addition, MeCP2 binding to the promoter of the $B d n f$ gene was increased and siRNAmediated reduction of $\mathrm{MeCP} 2$ levels rescued this effect and normalized Bdnf expression [73]. These findings suggest that aberrant interactions between $\mathrm{Htt}$ and $\mathrm{MeCP} 2$ are an additional mechanism that contributes to transcriptional dysregulation in HD.

\section{Histone post-translational modifications}

Chromatin consists of nucleosomes that contain 147 base pairs of DNA wrapped around an octomer of histone proteins comprised of two H2A, H2B, $\mathrm{H} 3$ and $\mathrm{H} 4$ histones. When the interaction between DNA and the octomer of histones is tight, resulting 


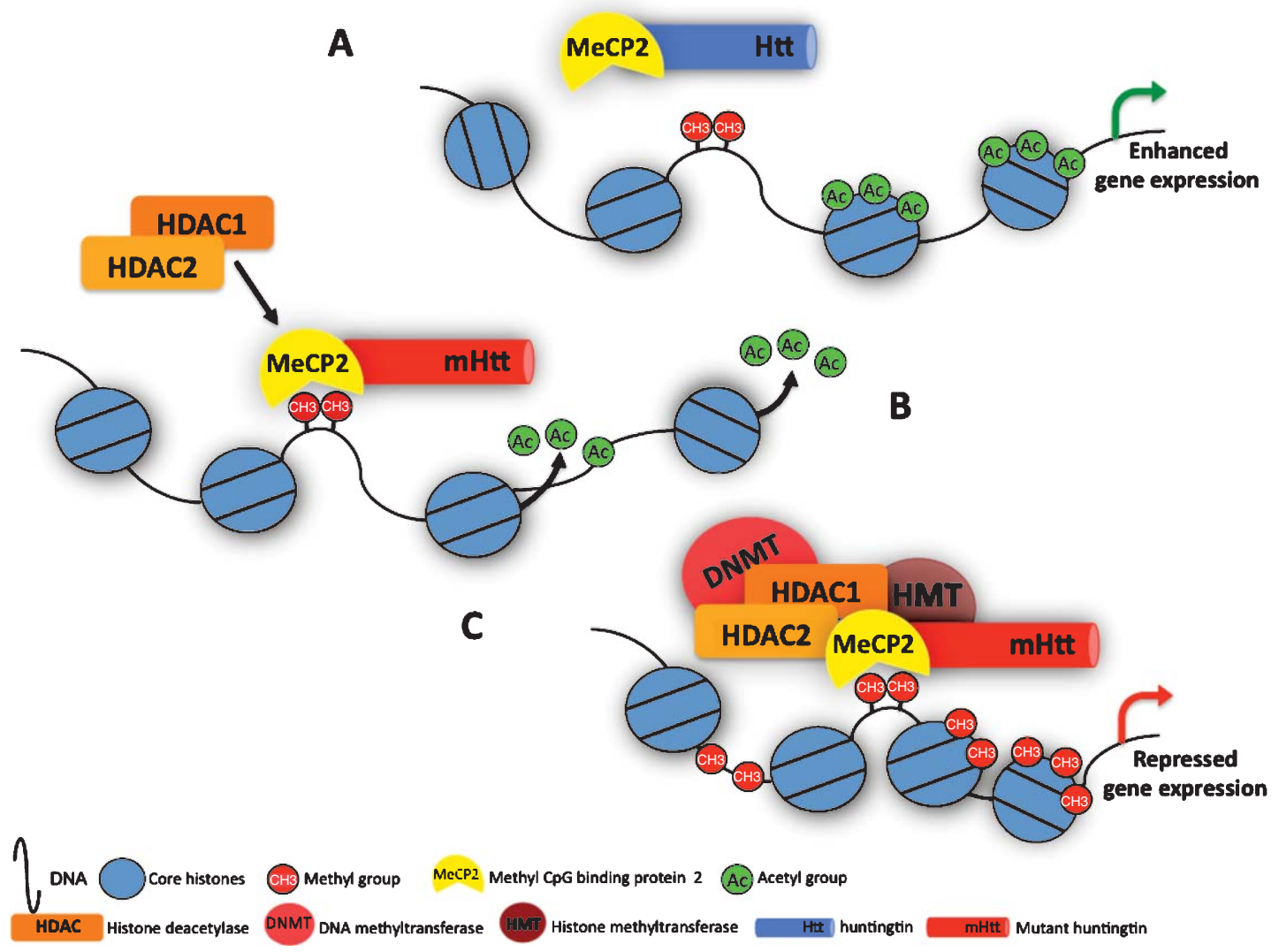

Fig. 1. Schematic of Htt-MeCP2 interactions A) Wildtype Htt and MeCP2 interact B) There is an increase in the interaction between mHtt and $\mathrm{MeCP} 2$ leading to an increase in the recruitment of MeCP2 to promoter regions. MeCP2 binding to methyl CpGs recruits HDAC1 and HDAC2 leading to deacetylation of histones $\mathrm{C}$ ) MeCP2/HDAC complex recruits methyltransferases (DNMTs), which add methyl groups $\left(\mathrm{CH}_{3}\right)$ to the C5 position of cytosine in the genome, as well as histone methyl transferases (HMT), which also add methyl groups to histones. Methylation of cytosines in $\mathrm{CpG}$ islands together with methylation of histones inhibits transcription.

in a compact nucleosome, this structure is referred to as heterochromatin. Conversely, a less constrained interaction between DNA and the histone octomer is known as euchromatin. Due to the compact structure of heterochromatin, DNA is less accessible to the transcriptional machinery thus facilitating transcriptional suppression. In contrast, the more relaxed structure of euchromatin is easily accessible and allows for enhanced gene expression. Combinations of posttranslational histone modifications alter the affinity of DNA for histone proteins, thereby positively or negatively affecting gene transcription [74]. The $\mathrm{N}$-terminal tails of histones contain amino acid residues that are sites for post-translational modifications, including acetylation, phosphorylation, methylation, ubiquitylation, SUMOylation, and ADP ribosylation, among others [75]. The addition or removal of these modifications occurs via specific enzymes, demonstrating the reversible nature of histone marks [75]. In HD, alterations in histone modifications have been studied extensively (Fig. 2) and the next section focuses on these studies.

\section{Histone acetylation}

Histone acetylation, the most studied epigenetic mark, leads to a change in chromatin structure from heterochromatin to euchromatin thus enhancing gene expression. Acetylation of lysine (K) residues on histone tails decreases the electrostatic interactions between histones and DNA [75] promoting a relaxed chromatin conformation that allows for the recruitment of transcription factors and the basal machinery to regulatory DNA sequences. Although this is a simplified description, hyperacetylation of histones at promoter regions is correlated with increased gene expression and hypoacetylation is associated with decreased gene expression [76]. In HD, several studies have reported a global reduction of acetylated histone levels [77-84]. However, other groups did not find these alterations in the same mouse models [85-89]. Specifically, studies 


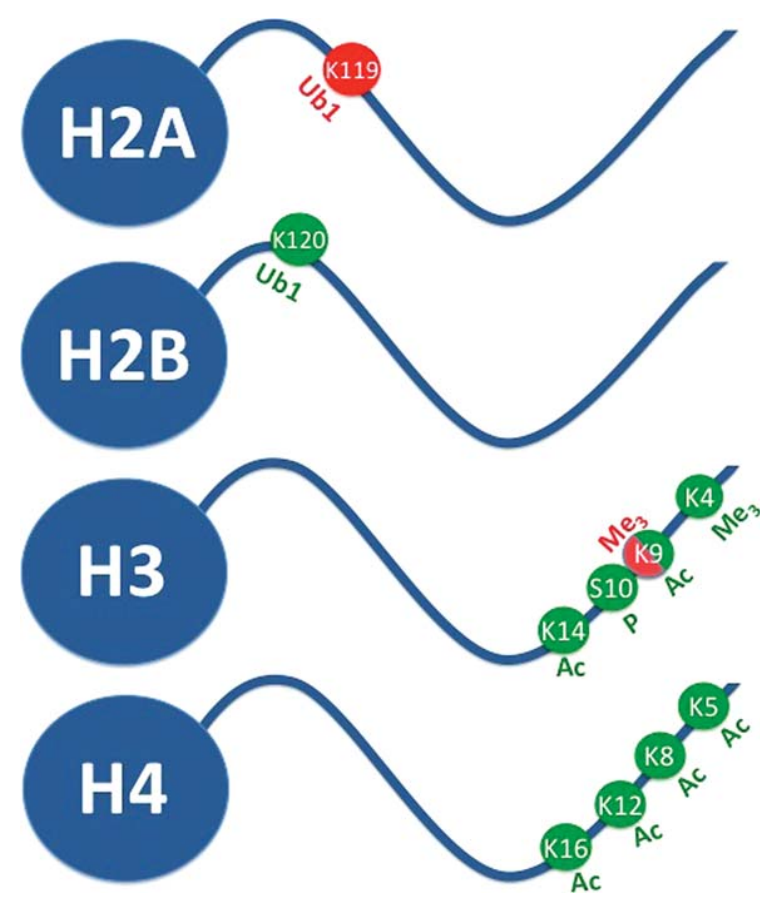

Fig. 2. Post-translational modifications of histones described in HD. Lysine (K) residues on the N-terminal tail of histones undergo modifications such as acetylation, methylation, or ubiquitylation, whereas serine (S) residues can be phosphorylated. Schematic representation of known histone modifications in HD that include: H2AK119ub1, H2BK120ub1, H3K4me3, H3K9me3, H3K9ac, H3S10p, H3K14ac, H3K9K14ac2, H4K5K8K12K16ac4. Green modifications represent facilitatory marks while red modifications represent inhibitory marks.

from our group and others demonstrated that histone acetylation was only decreased when associated with selective downregulated genes [88-90]. In addition, a number of hyperacetylation events were also revealed using genome-wide studies in HD mouse models [89, 91]. The extent of histone acetylation is regulated by the action of two opposing enzymes, histone acetyltransferases (HATs) and histone deacetylases (HDACs) [92], the role of which in HD will be reviewed in the following sections.

\section{Histone acetyltransferases (HATs)}

Dysregulation of histone acetylation in HD has been linked to CREB-binding protein (CBP), which functions as a HAT and is associated with several neurodegenerative diseases [92]. Specifically, CBP was located in intracellular inclusions in vitro, in brain tissue from animal models and in postmortem human HD patients [10, 34, 93]. Together these studies suggested that depletion of soluble CBP might affect transcription of genes relevant for neuronal survival. In agreement, a fifty percent reduction in CBP levels exacerbated neurodegeneration in a C. elegans HD model [94] and diminished the median life expectancy in the N171-82Q HD mouse model of HD [86]. Conversely, overexpression of CBP rescued the deficits in CBP/CREB-dependent transcription, histone hypoacetylation, and mHtt-induced toxicity in polyglutamine disease models [10, 34, 80, 95, 96]. These results have been confirmed in a wide array of HD models by independent research groups and more recently in neuronal populations from HD patients [97]. In addition, in vitro $\mathrm{mHtt}$ expression inhibited the HAT activity of CBP suggesting a more direct link between $\mathrm{mHtt}$ and CBP [98].

Despite the proposed association between altered CBP activity and mHtt-induced toxicity, the link between these cellular processes is not yet clear. Inclusions containing $\mathrm{mHtt}$ failed to significantly colocalize with or alter the nuclear distribution of CBP and other transcription factors in several HD mouse models [99-101]. In agreement, CBP exhibited a weak interaction with $\mathrm{mHtt}$ aggregates in a later stage of polyQ expression, whereas soluble mHtt exhibited a stronger interaction with CBP and inhibited HAT activity prior to the formation of inclusions in PC12 cells [102]. Soluble expanded polyQ fragments also demonstrated enhanced interaction with $\mathrm{CBP}$ and toxicity relative 
to the aggregated polyQ version [103]. These results agree with the observations from our group and others that altered gene expression is not necessarily connected with nuclear Htt aggregate formation in HD mice [37] and can occur in its absence [104, 105]. Thus, soluble mHtt could interact with transcription factors and chromatin-remodeling proteins to facilitate early pathological changes prior to the formation of nuclear inclusions. The conflicting findings linking CBP activity to soluble or aggregate forms of $\mathrm{mHtt}$ might be due to experimental confounds caused by in vitro overexpression of proteins that could force coaggregation or variable $\mathrm{mHtt}$ expression levels [80, $86,106]$. Finally, $H d h^{\mathrm{Q} 7 / \mathrm{Q} 111}$ knockin mice exhibit impairments in spatial and recognition memory along with decreased levels of CBP and acetylated histone $\mathrm{H} 3$ [82], suggesting that CBP may be important for the cognitive impairments seen in HD patients. It should be noted that despite the high degree of similarity to CBP, p300, another HAT, is absent from intracellular $\mathrm{mHtt}$ inclusions and is not degraded in the presence of $\mathrm{mHtt}$ [102]. More importantly, p300 does not rescue cell toxicity in overexpression assays [34]. These findings suggest that CBP may play a unique role, amongst HATs, in HD pathogenesis.

\section{Histone deacetylases (HDACs)}

In addition to HAT activity, HDAC activity is also altered in HD. The HDAC enzymes are divided into four classes: class I (HDACs 1, 2, 3 and 8), II (HDACs 4, 5, 6, 7, 9 and 10), III (NAD \pm sirtuin family) and IV (HDAC11). The first study measuring HDAC levels in HD demonstrated that there was an increase in the nuclear expression of HDAC5 without an overall change in transcript levels in human striatum and cortex [107]. In contrast, a recent study in R6/2 mice demonstrated that there was an increase in HDAC1 protein levels and a concomitant decrease in class II HDACs (particularly HDAC6) [108]. However, class I and II HDAC levels were not changed in cortical tissue from CAG140 knock-in mice or postmortem HD brain [108]. In agreement with the reported increase of HDAC1 expression in HD mice [108] decreasing HDAC1 via lithium promoted mHtt degradation in a HD cellular model [109]. However this relationship does not appear to extend to all class I HDACs since overexpression of wild-type Htt decreased HDAC3 activity, due to physical interactions between the two proteins [110].

Over the past several years a number of groups have assessed the role of HDACs in HD models via genetic knockout or knockdown approaches. The first report demonstrated that decreasing the HDAC 3 ortholog in the $C$. elegans HD model suppressed $\mathrm{mHtt}$-induced degeneration of sensory neurons but reducing any other orthologs of class I, II or III HDACs enhanced neurodegeneration [111]. In line with this study, decreasing Rpd3 (ortholog to HDAC1/2/8) or Sir2 (Sirt1) was neuroprotective but did not improve survival in a Drosophila HD model [112]. Interestingly, Bates and colleagues have demonstrated that decreasing HDACs (3, 6, 7 and Sirt2) in the R6/2 mouse via genetic crosses did not ameliorate the pathological phenotype associated with HD or reverse transcriptional deficits [113-116]. In contrast, a recent study from their group showed that reduction of HDAC4 delayed cytoplasmic $\mathrm{mHtt}$ aggregates, improved behavioral outcomes, and extended lifespan in R6/2 mice [117]. However, these effects appeared to be independent from the traditional role of HDACs in modifying gene transcription [117]. Finally, in HD cell lines challenged with cytotoxic insults, overexpression of HDAC7 was neuroprotective, though independent of its HDAC activity [118]. These studies demonstrate alterations in the activity of specific HAT and HDAC enzymes, however, it is not yet clear if these changes play a causal role in HD pathogenesis.

\section{Histone methylation}

While the effects of histone acetylation on gene expression are clear, the implications of histone methylation are not as straightforward since methylation causes both gene expression and silencing events. Histone methylation occurs via the addition of methyl groups to lysine $(\mathrm{K})$ or arginine $(\mathrm{R})$ residues on histone tails. This modification is relatively stable compared to histone acetylation, which does not alter the charge of the targeted amino acid residues [119]. Histone methylation can occur in mono-(me), di-(me2), or tri-methylated (me3) forms, with each methylation event yielding distinct and sometimes opposite effects on gene transcription [119]. Histone methylation at gene promoters can either enhance or repress transcription depending on the target amino acid [120]. For example, di- and tri-methylation of histone $\mathrm{H} 3$ on $\mathrm{K}$ residues 9 (H3K9me2/3) and 27 (H3K27me2/3) decrease gene transcription [119]. Conversely, tri-methylation of histone $\mathrm{H} 3$ on $\mathrm{K}$ residues 4 (H3K4me3) and $36(\mathrm{H} 3 \mathrm{~K} 36 \mathrm{me} 3)$ increases gene expression [119]. The extent of histone methylation is regulated at a locus by the action of histone methyltransferases (HMTs) and histone demethylases (HDMs) [120]. 
In both $\mathrm{R} 6 / 2$ mice and $\mathrm{HD}$ patients, $\mathrm{H} 3 \mathrm{~K} 4 \mathrm{me} 3$, a marker of active gene expression [121-123], is reduced at promoters of selective downregulated genes in cortical and striatal regions [124]. These results were confirmed using a genome-wide analysis in the R6/2 mouse. Specifically, this study demonstrated a widespread change in $\mathrm{H} 3 \mathrm{~K} 4 \mathrm{me} 3$ occupancy that was strongly associated with decreased transcription [124]. In addition, there were unusual patterns of $\mathrm{H} 3 \mathrm{~K} 4 \mathrm{me} 3$ occupancy downstream of the transcription start site suggesting that there might be selective regulatory control of Htt target genes that drive transcriptional alterations in HD [124]. H3K4me3 hypomethylation was hypothesized to be due to upregulation of the histone demethylase, lysine-specific demethylase 5C (KDM5C). Supporting this idea, knockdown of KDM5C increased the transcript levels of specific downregulated genes and attenuated toxicity in an HD fly model [124].

In contrast with $\mathrm{H} 3 \mathrm{~K} 4$ methylation, $\mathrm{H} 3 \mathrm{~K} 9$ methylation is a mark of gene repression. Histone H3K9 di-methylation (H3K9me2) and tri-methylation (H3K9me3) are increased in brain tissue from R6/2 and N171-82Q mice as well as in HD patients [78, 84, 125, 126]. This H3K9 hypermethylation originated from upregulation of upstream chromatin factors [126]. Specifically, there was a concurrent increase in the levels of $\mathrm{H} 3 \mathrm{~K} 9 \mathrm{me} 3$ and its specific histonelysine N-methyltransferase SET domain bifurcated 1 (SETDB1). This transcriptional upregulation of SETDB1 was proposed to be due to the GC-boxbinding transcription factors $\mathrm{Sp} 1$ and $\mathrm{Sp} 3$. While this finding agrees with the reported increase in Sp1 activity in HD [127], it contradicts with previous reports by our group and others demonstrating reduced function of Sp1 in HD models [37, 128, 129]. These conflicting results may be due in part to variation between different expression systems or HD models used in each study. In addition, the DNA-dependent ATPase/helicase alpha-thalassemia/mental retardation syndrome X-linked (ATRX) [130, 131] protein is increased in models of HD. ATRX is known to colocalize with $\mathrm{H} 3 \mathrm{~K} 9 \mathrm{me} 3$ and heterochromatin-binding protein 1 alpha $(H P 1 \alpha)$ [132]. Consistent with ATRX's role in heterochromatin condensation, there was an increase in pericentromeric heterochromatin clusters that was linked to enhanced expression of the transcription factor caudal type homeobox $2(\mathrm{Cdx} 2)$ and its binding occupancy at the ATRX promoter in R6/2 striatum [132]. These findings suggest a causal role between ATRX expression and the formation of heterochromatin clusters. Together these studies demonstrate that both hypo- and hypermethylation play important roles in regulating gene transcription in HD.

\section{Histone phosphorylation}

Histone phosphorylation is another posttranslational modification associated with increased gene transcription [120]. Phosphorylation of serine 10 on histone H3 promotes HAT activity, phosphoacetylation of neighboring amino acid residues, and inhibits repressive methylation marks on H3 [75]. Yazawa and colleagues were the first group to report aberrant phosphorylation of histone $\mathrm{H} 3$ in polyQ diseases [133]. Later it was demonstrated that histone H3 phosphorylation (H3S10p) and expression of its downstream target gene c-Fos were decreased in striatal neurons transfected with expanded Htt [134]. The phosphorylation level of $\mathrm{H} 3 \mathrm{~S} 10 \mathrm{p}$ is extremely low under basal conditions, but it is significantly upregulated following neuronal activation in a rapid and transient manner [135-137]. Thus, it has been proposed that impaired H3S10p induction is due to downregulation of the upstream kinase mitogen- and stress-activated protein kinase-1 (MSK-1). In agreement with this hypothesis, overexpression of MSK-1 restored full induction of $\mathrm{H} 3 \mathrm{~S} 10 \mathrm{p}$ and c-Fos expression and prevented striatal death in vitro and in vivo [134, 138] via cooperative action with transcription factors, such as CREB, to activate pro-survival factors.

Another instance of histone phosphorylation occurs with the 'universal' histone variant H2A.X, which differs from canonical H2A in C-terminal phosphorylation and in a few amino acids in the primary sequence. H2A.X is phosphorylated at S139 by ataxia telangiectasia mutated kinase (ATM) generating $\gamma \mathrm{H} 2 \mathrm{~A} . \mathrm{X}$ in a cellular model as well as in $\mathrm{R} 6 / 2$ mice due to DNA damage $[139,140]$. $\gamma \mathrm{H} 2 \mathrm{~A} . \mathrm{X}$ and breast cancerassociated 1 (BRCA1), another ATM substrate, are uncoupled in the presence of $\mathrm{mHtt}$, leading to increased DNA breaks in neurons [141]. Moreover, activation of $\gamma \mathrm{H} 2 \mathrm{~A}$.X facilitates DNA repair [142]. However, attenuating the elevated ATM signaling seen in HD leads to decreased mHtt-induced cell death in various HD animal models and in pluripotent stem cells from human HD patients [143]. These findings suggest that levels of $\gamma \mathrm{H} 2 \mathrm{~A}$.X and ATM must be tightly controlled in HD in order to protect neurons from damage without inducing deleterious, apoptotic effects.

\section{Histone monoubiquitylation}

Histone monoubiquitylation occurs through the covalent attachment of the ubiquitin protein to $\mathrm{K}$ 
residues using an E3 ubiquitin ligase. Histone H2A is monoubiquitylated (H2Aub1) at K119 by the Polycomb repressor complex PRC1. H2Aub1 is associated with silencing of developmental genes, pericentromeric regions, and the inactive $\mathrm{X}$-chromosome [144]. Prior H3K27 methylation by the Polycomb complex PRC2 is generally required for $\mathrm{H} 2 \mathrm{~A}$ monoubiquitylation. While H2A ubiquitylation leads to transcriptional repression, histone $\mathrm{H} 2 \mathrm{~B}$ monoubiquitylated (H2Bub1) at K120 is typically associated with active genes. H2Bub1 is a prerequisite step to histone $\mathrm{H} 3$ methylation at $\mathrm{K} 4$ and $\mathrm{K} 79$, and more importantly, H2Bub1 regulates general chromatin structure by ensuring integrity of histone positioning.

Previous studies from our group and others demonstrated that overall levels of H2Aub1 were increased, independent of the ubiquitin-proteasome system [145-147], whereas H2Bub1 levels were reduced in the R6/2 mouse brain [146]. Furthermore, manipulation of E3 ubiquitin ligase ring finger proteins in the mutant STHdh cell lines demonstrated that the ring finger protein 2 (Rnf2 or Ring2) regulates H2Aub1 and downstream methylation of H3K9. Conversely, Rnf20 (homolog to yeast Bre1) regulates H2Bub1 and downstream methylation of H3K4 [146]. Although global elevation of $\mathrm{H} 2 \mathrm{Aub} 1$ has been demonstrated in HD mice, conflicting evidence exists regarding the link between transcriptional activity and ubiquitylation of promoters for individual genes [146, 147]. Together these findings point to the potential involvement of the Polycomb Repressive Complexes (PRC) in $\mathrm{HD}$, although their link to transcriptional activity was unclear until recently. A new study recently demonstrated that expanding the polyQ tract in $\mathrm{mHtt}$ enhances its ability to facilitate PRC2 and thereby alter the chromatin landscape in pluripotent and lineage restricted progenitor cells [148]. Specifically, Htt was necessary for the proper deposition, maintenance, and removal of H3K27me3, a histone mark that is deposited by PRC2 [148]. Although further studies are required to fully understand the nature of Htt's interaction with PRC as well as with other epigenetic regulators, these findings demonstrate that $\mathrm{mHtt}$ can regulate the broader epigenetic machinery in order to orchestrate alterations in higher order chromatin states [148].

\section{Epigenetic-based therapies for the treatment of HD}

\section{HDAC inhibitors}

Given the role of histone modifying enzymes in regulating gene expression, the use of HDAC inhibitors as novel therapeutic approaches for the treatment of $\mathrm{HD}$ has gained considerable attention. The potential role for HDAC inhibitors (HDACi) in HD was first described in two influential papers which demonstrated that administration of broad-spectrum HDACi (sodium butyrate $(\mathrm{NaB})$, suberoylanilide hydroxamic acid (SAHA), and trichostatin A (TSA)) rescued cell death and degeneration in models of polyQ disorders [98, 149]. Following those studies, the beneficial effects of HDACi have been described in numerous cellular and animal models of HD [150]. It has been proposed that HDACi administration yields therapeutic effects by increasing histone acetylation associated with gene promoters and thereby reversing deficits in gene expression. However, HDACi may also exert their effects by altering other marks, such as reducing the repressive $\mathrm{H} 3 \mathrm{~K} 9 \mathrm{me} 2$ and $\mathrm{H} 2 \mathrm{Aub} 1$ marks, due to the cross-talk between different histone modifications $[78,88]$. In addition, a recent study demonstrated that HDAC1/3 inhibition, via HDAC4b treatment, produced widespread changes in DNA methylation, including $\mathrm{CpG}$ methylation at the genomic locus for the lysine-specific methylase 5D (KDM5D), in fibroblasts from human HD patients [151]. These alterations in other epigenetic marks may assist HDACi in restoring normal gene expression. Additionally, HDACi treatment could provide therapeutic benefit by directly altering the expression of HDAC enzymes. For example, SAHA treatment altered the expression of HDAC2 and 4 protein levels, and HDAC7 and 11 RNA levels [113, 117].

Despite promising pre-clinical data with HDACi, broad spectrum HDAC inhibition may have unintended effects in human HD patients. Therefore, recent efforts have focused on the development of more selective HDACi $[152,153]$. An important issue for the development of HDACi as therapeutics is the identification of the HDAC enzymes critical for the disease process. There are now 18 known human HDAC enzymes [154] each of which have distinct roles in the body. HDAC1 and HDAC3 have been implicated in neurotoxicity and the pathological mechanisms related to polyQ disease [153]. Moreover, HDACi selective for HDAC1/3 ameliorated pathological processes in cellular and animal models of HD [90, 155, 156]. Recent studies by our collaborators along with our group demonstrate that the HDACi $4 \mathrm{~b}$ and related compounds exhibit more specificity for HDAC1 and HDAC3 while still producing significant improvements in polyQ-induced deficits in HD models $[90,156]$. Interesting, HDACi $4 \mathrm{~b}$ treatment has also been shown to have transgenerational effects, improving HD phenotypic behaviors 
in untreated F1 male offspring [151]. Despite these promising findings, recent concerns with oral administration of HDACi $4 \mathrm{~b}$ may limit future use of this compound [157]. Additional selective HDACi are currently under development for the treatment of $\mathrm{HD}$ and other neurodegenerative diseases [158]. It will be important to assess whether these novel compounds yield similar pre-clinical therapeutic benefits to broad spectrum HDACi.

It should be noted that there are several concerns in regards to the genomic effects of HDACi treatment. Acute treatment with the HDAC TSA preferentially hyperacetylated active loci already premarked with $\mathrm{H} 3 \mathrm{~K} 4 \mathrm{me} 3$ and $\mathrm{H} 3 \mathrm{~K} 9 \mathrm{~K} 14 \mathrm{ac}$ at the transcription start site [159]. This finding suggests that HDAC inhibition may favor transcriptionally permissive states. Another puzzling result is the fact that microarray studies revealed a relatively limited number of corrected genes following HDACi treatment in HD models [77, $78,84]$. Therefore, there is a possibility that HDACi exert their beneficial effects by altering other cellular processes besides transcriptional regulation.

In addition to histones, hundreds of proteins can be acetylated [160] and therefore altered in response to HDACi treatment [161]. Thus, HDACi could produce beneficial outcomes via combinatorial effects on histones and non-histone substrates, including cytoskeletal and mitochondrial proteins as well as transcription factors. Importantly, acetylation K444 on Htt can promote its clearance via the autophagiclysosomal system [162]. Similarly, AcK9/pS13/pS16 are also linked to autophagic degradation and can be altered by the HDACi 4b [156, 163]. HDACi treatment also increased tubulin acetylation at K40 and rescued in vitro microtubule-dependent transport deficits, including trafficking of BDNF-containing vesicles [164]. Since this trafficking is disrupted in HD [165], HDACi treatment may also ameliorate HD symptomatology through restoring normal BDNF levels in the striatum.

\section{Methylation inhibiting drugs}

Methyltransferase inhibitors have been tested in various neurological disorders. However, to date they have not been utilized in HD. Despite this, histone methylation can be indirectly altered by GCbinding anthracyclines, such as mithramycin $\mathrm{A}$ and chromomycin [166]. Anthracyclines are bacterial compounds with antibiotic and anticancer properties that interact with the minor groove of DNA and inhibit binding of GC-rich-binding transcription factors like Sp1 family members. In 82Q HD mice, mithramycin or chromomycin treatment reversed the hypoacetylation of histones $\mathrm{H} 3$ and $\mathrm{H} 4$ and hypermethylation of histone H3, extended survival, improved motor phenotypes and increased brain volume [84]. Similarly, mithramycin treatment attenuated hypermethylation of histone $\mathrm{H} 4$, extended survival and improved motor phenotypes in R6/2 mice [125]. Mithramycin treatment also restored the expression of the methyltransferase SETDB1, a key enzyme that regulates histone methylation [126]. Given these findings, future pre-clinical studies will be important to further determine if anthracycline treatment could be a potential treatment for HD.

\section{CONCLUSIONS}

As reviewed above, alterations in gene expression and the epigenome are important and early mechanisms underlying HD pathology. Importantly, Htt protein itself interacts with a number of transcription factors as well as epigenetic regulators. Therefore, it was hypothesized that reversal of epigenetic marks associated with HD may restore, at least partially, the normal transcriptional program and ameliorate the pathological phenotype. However, it remains to be determined to what extent changes in the epigenome play a causal role in transcriptional dysregulation. Genome-wide studies have demonstrated that the relationship between alterations in the epigenome and gene expression changes is complicated. Up to this point, only a few epigenetic marks have been analyzed using genome-wide approaches [65, 91, 92, 124, 147]. These findings demonstrate that alterations in the epigenome in HD are more complex than previously appreciated and highlight the importance of targeting epigenetic "signatures" as opposed to individual epigenetic marks for the treatment of HD. In addition, these studies challenge our current view regarding the method by which epigenetic mechanisms regulate gene expression given that co-occurrence of changes in gene expression and epigenetic modifications does not necessarily involve a causal relationship. This puzzling result could be due to several issues including our incomplete understanding of the role of epigenetics in the CNS under normal conditions. Moreover, a number of additional epigenetic marks remain to be examined in HD. It is conceivable that combinations of epigenetic marks converging on selective loci are responsible for enhancing or attenuating transcription. Therefore, more in depth and comprehensive approaches employing novel genome- and epigenome-wide methods of analysis will help to assess and identify the sets of 
genes and epigenetic mechanisms that are involved in these processes. Finally, a more extensive and complete understanding of chromatin states and 3D chromatin structure is critical as these structural changes could also alter transcription.

\section{CONFLICT OF INTEREST}

The authors have no conflict of interest to report.

\section{REFERENCES}

[1] Bates G, Harper P, Jones L, editors. Huntington's Disease. 3rd ed. New York: Oxford University Press; 2002.

[2] Albin RL, Young AB, Penney JB. The functional anatomy of basal ganglia disorders. Trends Neurosci. 1989;12(10):36675 .

[3] Koroshetz WJ, Jenkins BG, Rosen BR, Beal MF. Energy metabolism defects in Huntington's disease and effects of coenzyme Q10. Ann Neurol. 1997;41(2):160-5.

[4] Hedreen JC, Peyser CE, Folstein SE, Ross CA. Neuronal loss in layers V and VI of cerebral cortex in Huntington's disease. Neurosci Lett. 1991;133(2):257-61.

[5] Vonsattel JPG, DiFiglia M. Huntington disease. J Neuropathol Exp Neurol. 1998;57(5):369-84.

[6] Huntington's Disease Collaborative Research Group. A novel gene containing a trinucleotide repeat that is unstable in Huntington's disease chromosomes. Cell. 1993;72:97183.

[7] Duyao MP, Ambrose CM, Myers RH, Novoletto A, Persichetti F, Frontali M, Folstein SE, Ross C, Franz ML, Abbott M, Gray J, Conneally PM, Young A, Penney J, Hollingsworth Z, Shoulson I, Lazzarini AM, Falek A, Koroshetz W, Sax DS, Bird E, Vonsattel JP, Bonilla E, Alvir J, Bickham Conde J, Cha J-H, Dure L, Gomez F, Ramos M, Sanchez-Ramos J, Snodgrass SR, de Young M, Moscowitz C, Penchaszadeh G, MacFarlane H, Anderson MA, Jenkins B, Srinidhi J, Barnes G, Gusella JF, MacDonald ME. Trinucleotide repeat length instability and age of onset in Huntington's disease. Nat Genet. 1993;4:387-92.

[8] Cha JH. Transcriptional signatures in Huntington's disease. Prog Neurobiol. 2007;83(4):228-48.

[9] Cha JH, Kosinski CM, Kerner JA, Alsdorf SA, Mangiarini L, Davies SW, Penney JB, Bates GP, Young AB. Altered brain neurotransmitter receptors in transgenic mice expressing a portion of an abnormal human huntington disease gene. Proc Natl Acad Sci U S A. 1998;95(11):6480-5.

[10] Steffan JS, Kazantsev A, Spasic-Boskovic O, Greenwald M, Zhu YZ, Gohler H, Wanker EE, Bates GP, Housman DE, Thompson LM. The Huntington's disease protein interacts with $\mathrm{p} 53$ and CREB-binding protein and represses transcription. Proc Natl Acad Sci U S A. 2000;97(12):6763-8.

[11] Sugars KL, Rubinsztein DC. Transcriptional abnormalities in Huntington disease. Trends Genet. 2003;19(5):233-8.

[12] DiFiglia M. Excitotoxic injury of the neostriatum: A model for Huntington's disease. Trends Neurosci. 1990;13(7): 286-9.

[13] Browne SE, Bowling AC, MacGarvey U, White JK, MacDonald ME, Beal MF, editors. Evidence of bioenergetic defects in Huntington's disease post-mortem brain, and in a transgenic mouse model of Huntington's disease. 17th International Meeting of the World Federation of Neurology
Research Group on Huntington's Disease; 1997; Syndey, Australia.

[14] Beal MF. Mitochondrial dysfunction in neurodegenerative diseases. Biochim Biophys Acta Bio Energetics. 1998;1366(1-2):211-23.

[15] Lodi R, Schapira AH, Manners D, Styles P, Wood NW, Taylor DJ, Warner TT. Abnormal in vivo skeletal muscle energy metabolism in Huntington's disease and dentatorubropallidoluysian atrophy. Ann Neurol. 2000;48(1):72-6.

[16] Wellington CL, Ellerby LM, Hackam AS, Margolis RL, Trifiro MA, Singaraja R, McCutcheon K, Salvesen GS, Propp SS, Bromm M, Rowland KJ, Zhang TQ, Rasper D, Roy S, Thornberry N, Pinsky L, Kakizuka A, Ross CA, Nicholson DW, Bredesen DE, Hayden MR. Caspase cleavage of gene products associated with triplet expansion disorders generates truncated fragments containing the polyglutamine tract. J Biol Chem. 1998;273(15): 9158-67.

[17] Ona VO, Li M, Vonsattel JP, Andrews LJ, Khan SQ, Chung WM, Frey AS, Menon AS, Li XJ, Stieg PE, Yuan J, Penney JB, Young AB, Cha JH, Friedlander RM. Inhibition of caspase-1 slows disease progression in a mouse model of Huntington's disease [see comments]. Nature. 1999;399(6733):263-67

[18] Sanchez I, Xu CJ, Juo P, Kakizaka A, Blenis J, Yuan J. Caspase- 8 is required for cell death induced by expanded polyglutamine repeats. Neuron. 1999;22(3):623-33.

[19] Rigamonti D, Bauer JH, De-Fraja C, Conti L, Sipione S, Sciorati C, Clementi E, Hackam A, Hayden MR, Li Y, Cooper JK, Ross CA, Govoni S, Vincenz C, Cattaneo E. Wild-type huntingtin protects from apoptosis upstream of caspase-3. J Neurosci. 2000;20(10):3705-13.

[20] Luthi-Carter R, Apostol BL, Dunah AW, DeJohn MM, Farrell LA, Bates GP, Young AB, Standaert DG, Thompson LM, Cha JH. Complex alteration of NMDA receptors in transgenic Huntington's disease mouse brain: Analysis of mRNA and protein expression, plasma membrane association, interacting proteins, and phosphorylation. Neurobiol Dis. 2003;14(3):624-36.

[21] Luthi-Carter R, Strand A, Peters NL, Solano SM, Hollingsworth ZR, Menon AS, Frey AS, Spektor BS, Penney EB, Schilling G, Ross CA, Borchelt DR, Tapscott SJ, Young $\mathrm{AB}$, Cha JH, Olson JM. Decreased expression of striatal signaling genes in a mouse model of Huntington's disease. Hum Mol Genet. 2000;9(9):1259-71.

[22] Augood SJ, Faull RL, Emson PC. Dopamine D1 and D2 receptor gene expression in the striatum in Huntington's disease. Ann Neurol. 1997;42(2):215-21.

[23] Cha JH, Frey AS, Alsdorf SA, Kerner JA, Kosinski CM, Mangiarini L, Penney JB, Jr., Davies SW, Bates GP, Young AB. Altered neurotransmitter receptor expression in transgenic mouse models of Huntington's disease. Philos Trans R Soc Lond B Biol Sci. 1999;354(1386):981-9.

[24] Valor LM. Transcription, epigenetics and ameliorative strategies in Huntington's disease: A genome-wide perspective. Mol Neurobiol. 2015;51(1):406-23.

[25] Luthi-Carter R, Hanson SA, Strand AD, Bergstrom DA, Chun W, Peters NL, Woods AM, Chan EY, Kooperberg C, Krainc D, Young AB, Tapscott SJ, Olson JM. Dysregulation of gene expression in the R6/2 model of polyglutamine disease: Parallel changes in muscle and brain. Hum Mol Genet. 2002;11(17):1911-26.

[26] Schilling G, Jinnah HA, Gonzales V, Coonfield ML, Kim Y, Wood JD, Price DL, Li XJ, Jenkins N, Copeland N, Moran T, Ross CA, Borchelt DR. Distinct behavioral and 
neuropathological abnormalities in transgenic mouse models of HD and DRPLA. Neurobiol Dis. 2001;8(3):405-18.

[27] Weeks RA, Piccini P, Harding AE, Brooks DJ. Striatal D1 and D2 dopamine receptor loss in asymptomatic mutation carriers of Huntington's disease. Ann Neurol. 1996;40(1):49-54.

[28] Bibb JA, Yan Z, Svenningsson P, Snyder GL, Pieribone VA, Horiuchi A, Nairn AC, Messer A, Greengard P. Severe deficiencies in dopamine signaling in presymptomatic Huntington's disease mice. Proc Natl Acad Sci U S A. 2000;97(12):6809-14.

[29] Glynn D, Bortnick RA, Morton AJ. Complexin II is essential for normal neurological function in mice. Hum Mol Genet. 2003;12(19):2431-48

[30] Hu H, McCaw EA, Hebb AL, Gomez GT, Denovan-Wright EM. Mutant huntingtin affects the rate of transcription of striatum-specific isoforms of phosphodiesterase 10A. Eur J Neurosci. 2004;20(12):3351-63.

[31] McCaw EA, Hu H, Gomez GT, Hebb AL, Kelly ME, Denovan-Wright EM. Structure, expression and regulation of the cannabinoid receptor gene (CB1) in Huntington's disease transgenic mice. Eur J Biochem. 2004;271(2324):4909-20.

[32] Hodges A, Strand AD, Aragaki AK, Kuhn A, Sengstag T, Hughes G, Elliston LA, Hartog C, Goldstein DR, Thu D, Hollingsworth ZR, Collin F, Synek B, Holmans PA, Young AB, Wexler NS, Delorenzi M, Kooperberg C, Augood SJ, Faull RL, Olson JM, Jones L, Luthi-Carter R. Regional and cellular gene expression changes in human Huntington's disease brain. Hum Mol Genet. 2006;15(6):965-77.

[33] Borovecki F, Lovrecic L, Zhou J, Jeong H, Then F, Rosas HD, Hersch SM, Hogarth P, Bouzou B, Jensen RV, Krainc D. Genome-wide expression profiling of human blood reveals biomarkers for Huntington's disease. Proc Natl Acad Sci U S A. 2005;102(31):11023-8.

[34] Nucifora FC, Jr., Sasaki M, Peters MF, Huang H, Cooper JK, Yamada M, Takahashi H, Tsuji S, Troncoso J, Dawson VL, Dawson TM, Ross CA. Interference by huntingtin and atrophin-1 with cbp-mediated transcription leading to cellular toxicity. Science. 2001;291(5512):2423-8.

[35] Huang CC, Faber PW, Persichetti F, Mittal V, Vonsattel JP, MacDonald ME, Gusella JF. Amyloid formation by mutant huntingtin: Threshold, progressivity and recruitment of normal polyglutamine proteins. Somat Cell Mol Genet. 1998;24(4):217-33

[36] Steffan JS, Kazantsev A, Spasic-Boskovic O, Greenwald M, Zhu Y-Z, Gohler H, Wanker E, Bates GP, Housman DE, Thompson LM. The Huntington's disease protein interacts with p53 and CBP and represses transcription. Proc Nat Acad Sci U S A. 2000;97:6763-8

[37] Dunah AW, Jeong H, Griffin A, Kim YM, Standaert DG, Hersch SM, Mouradian MM, Young AB, Tanese N, Krainc D. Sp1 and TAFII130 transcriptional activity disrupted in early Huntington's disease. Science. 2002;296(5576):223843.

[38] Marcora E, Kennedy MB. The Huntington's disease mutation impairs Huntingtin's role in the transport of NF-kappaB from the synapse to the nucleus. Hum Mol Genet. 2010;19(22):4373-84

[39] Sadri-Vakili G, Menon AS, Farrell LA, Keller-McGandy CE, Cantuti-Castelvetri I, Standaert DG, Augood SJ, Yohrling GJ, Cha JH. Huntingtin inclusions do not downregulate specific genes in the R6/2 Huntington's disease mouse. Eur J Neurosci. 2006;23(12):3171-75.
[40] Wellington CL, Ellerby LM, Hackam AS, Margolis RL, Trifiro MA, Singaraja R, McCutcheon K, Salvesen GS, Propp SS, Bromm M, Rowland KJ, Zhang T, Rasper D, Roy S, Thornberry N, Pinsky L, Kakizuka A, Ross CA, Nicholson DW, Bredesen DE, Hayden MR. Caspase cleavage of gene products associated with triplet expansion disorders generates truncated fragments containing the polyglutamine tract. J Biol Chem. 1998;273(15):9158-67.

[41] Zuccato C, Tartari M, Crotti A, Goffredo D, Valenza M, Conti L, Cataudella T, Leavitt BR, Hayden MR, Timmusk T, Rigamonti D, Cattaneo E. Huntingtin interacts with REST/NRSF to modulate the transcription of NRSEcontrolled neuronal genes. Nat Genet. 2003;35(1):76-83.

[42] Gerber HP, Seipel K, Georgiev O, Hofferer M, Hug M, Rusconi S, Schaffner W. Transcriptional activation modulated by homopolymeric glutamine and proline stretches. Science. 1994;263(5148):808-11.

[43] Karlin S, Burge C. Trinucleotide repeats and long homopeptides in genes and proteins associated with nervous system disease and development. Proc Natl Acad Sci U S A. 1996;93(4):1560-5.

[44] Benn CL, Sun T, Sadri-Vakili G, McFarland KN, DiRocco DP, Yohrling GJ, Clark TW, Bouzou B, Cha JH. Huntingtin modulates transcription, occupies gene promoters in vivo, and binds directly to DNA in a polyglutamine-dependent manner. J Neurosci. 2008;28(42):10720-33.

[45] Bird A. Perceptions of epigenetics. Nature. 2007; 447(7143):396-8.

[46] Siegmund KD, Connor CM, Campan M, Long TI, Weisenberger DJ, Biniszkiewicz D, Jaenisch R, Laird PW, Akbarian S. DNA methylation in the human cerebral cortex is dynamically regulated throughout the life span and involves differentiated neurons. PLoS One. 2007;2(9):e895.

[47] Tsankova N, Renthal W, Kumar A, Nestler EJ. Epigenetic regulation in psychiatric disorders. Nat Rev Neurosci. 2007;8(5):355-67.

[48] Kanduri C. Long noncoding RNA and epigenomics. Adv Exp Med Biol. 2011;722:174-95.

[49] Sadri-Vakili G. Cocaine triggers epigenetic alterations in the corticostriatal circuit. Brain Res. 2014; pii: S00068993(14)01342-0. doi: 10.1016/j.brainres.2014.09.069.

[50] Suzuki MM, Bird A. DNA methylation landscapes: Provocative insights from epigenomics. Nat Rev Genet. 2008;9(6):465-76.

[51] Guo JU, Su Y, Zhong C, Ming GL, Song H. Emerging roles of TET proteins and 5-hydroxymethylcytosines in active DNA demethylation and beyond. Cell Cycle. 2011;10(16):2662-68.

[52] Guibert S, Weber M. Functions of DNA methylation and hydroxymethylation in mammalian development. Curr Top Dev Biol. 2013;104:47-83.

[53] Lister R, Mukamel EA, Nery JR, Urich M, Puddifoot CA, Johnson ND, Lucero J, Huang Y, Dwork AJ, Schultz MD, Yu M, Tonti-Filippini J, Heyn H, Hu S, Wu JC, Rao A, Esteller M, He C, Haghighi FG, Sejnowski TJ, Behrens MM, Ecker JR. Global epigenomic reconfiguration during mammalian brain development. Science. 2013;341(6146): 1237905.

[54] Jaenisch R, Bird A. Epigenetic regulation of gene expression: How the genome integrates intrinsic and environmental signals. Nat Genet. 2003;33 Suppl:245-54.

[55] Franklin TB, Russig H, Weiss IC, Graff J, Linder N, Michalon A, Vizi S, Mansuy IM. Epigenetic transmission of the impact of early stress across generations. Biol Psychiatry. 2010;68(5):408-15. 
[56] Guerrero-Bosagna C, Settles M, Lucker B, Skinner MK. Epigenetic transgenerational actions of vinclozolin on promoter regions of the sperm epigenome. PLoS One. 2010;5(9):pii: e13100. doi: 10.1371/journal.pone.0013100.

[57] Liu L, van Groen T, Kadish I, Tollefsbol TO. DNA methylation impacts on learning and memory in aging. Neurobiol Aging. 2009;30(4):549-60.

[58] Miller CA, Gavin CF, White JA, Parrish RR, Honasoge A, Yancey CR, Rivera IM, Rubio MD, Rumbaugh G, Sweatt JD. Cortical DNA methylation maintains remote memory. Nat Neurosci. 2010;13(6):664-6.

[59] Day JJ, Sweatt JD. DNA methylation and memory formation. Nat Neurosci. 2010;13(11):1319-23.

[60] Jakovcevski M, Akbarian S. Epigenetic mechanisms in neurological disease. Nat Med. 2012;18(8):1194-204.

[61] Robertson KD. DNA methylation and human disease. Nat Rev Genet. 2005;6(8):597-610.

[62] Seredenina T, Luthi-Carter R. What have we learned from gene expression profiles in Huntington's disease? Neurobiol Dis. 2012;45(1):83-98.

[63] Zajac MS, Pang TY, Wong N, Weinrich B, Leang LS, Craig JM, Saffery R, Hannan AJ. Wheel running and environmental enrichment differentially modify exon-specific BDNF expression in the hippocampus of wild-type and pre-motor symptomatic male and female Huntington's disease mice. Hippocampus. 2010;20(5):621-36.

[64] Villar-Menendez I, Blanch M, Tyebji S, Pereira-Veiga T, Albasanz JL, Martin M, Ferrer I, Perez-Navarro E, Barrachina M. Increased 5-methylcytosine and decreased 5hydroxymethylcytosine levels are associated with reduced striatal A2AR levels in Huntington's disease. Neuromolecular Med. 2013;15(2):295-309.

[65] $\mathrm{Ng} \mathrm{CW}$, Yildirim F, Yap YS, Dalin S, Matthews BJ, Velez PJ, Labadorf A, Housman DE, Fraenkel E. Extensive changes in DNA methylation are associated with expression of mutant huntingtin. Proc Natl Acad Sci U S A. 2013;110(6): 2354-59.

[66] Wang F, Yang Y, Lin X, Wang JQ, Wu YS, Xie W, Wang D, Zhu S, Liao YQ, Sun Q, Yang YG, Luo HR, Guo C, Han C, Tang TS. Genome-wide loss of 5-hmC is a novel epigenetic feature of Huntington's disease. Hum Mol Genet. 2013;22(18):3641-53.

[67] Thomas B, Matson S, Chopra V, Sun L, Sharma S, Hersch S, Rosas HD, Scherzer C, Ferrante R, Matson W. A novel method for detecting 7-methyl guanine reveals aberrant methylation levels in Huntington disease. Anal Biochem. 2013;436(2):112-20.

[68] Varley KE, Gertz J, Bowling KM, Parker SL, Reddy TE, Pauli-Behn F, Cross MK, Williams BA, Stamatoyannopoulos JA, Crawford GE, Absher DM, Wold BJ, Myers RM. Dynamic DNA methylation across diverse human cell lines and tissues. Genome Res. 2013;23(3):555-67.

[69] Xie W, Barr CL, Kim A, Yue F, Lee AY, Eubanks J, Dempster EL, Ren B. Base-resolution analyses of sequence and parentof-origin dependent DNA methylation in the mouse genome. Cell. 2012;148(4):816-31.

[70] Globisch D, Munzel M, Muller M, Michalakis S, Wagner M, Koch S, Bruckl T, Biel M, Carell T. Tissue distribution of 5hydroxymethylcytosine and search for active demethylation intermediates. PLoS One. 2010;5(12):e15367.

[71] Li W, Liu M. Distribution of 5-hydroxymethylcytosine in different human tissues. J Nucleic Acids. 2011;2011: 870726.

[72] Song CX, He C. The hunt for 5-hydroxymethylcytosine: The sixth base. Epigenomics. 2011;3(5):521-23.
[73] McFarland KN, Huizenga MN, Darnell SB, Sangrey GR, Berezovska O, Cha JH, Outeiro TF, Sadri-Vakili G. MeCP2: A novel Huntingtin interactor. Hum Mol Genet. 2014;23(4):1036-44.

[74] Strahl BD, Allis CD. The language of covalent histone modifications. Nature. 2000;403(6765):41-5.

[75] Kouzarides T. Chromatin modifications and their function. Cell. 2007;128(4):693-705.

[76] Kurdistani SK, Tavazoie S, Grunstein M. Mapping globa histone acetylation patterns to gene expression. Cell. 2004;117(6):721-33.

[77] Ferrante RJ, Kubilus JK, Lee J, Ryu H, Beesen A, Zucker B, Smith K, Kowall NW, Ratan RR, Luthi-Carter R, Hersch SM. Histone deacetylase inhibition by sodium butyrate chemotherapy ameliorates the neurodegenerative phenotype in Huntington's disease mice. J Neurosci. 2003;23(28):9418-27.

[78] Gardian G, Browne SE, Choi DK, Klivenyi P, Gregorio J Kubilus JK, Ryu H, Langley B, Ratan RR, Ferrante RJ, Beal MF. Neuroprotective effects of phenylbutyrate in the N17182Q transgenic mouse model of Huntington's disease. J Biol Chem. 2005;280(1):556-63.

[79] Igarashi S, Morita H, Bennett KM, Tanaka Y, Engelender S, Peters MF, Cooper JK, Wood JD, Sawa A, Ross CA. Inducible PC12 cell model of Huntington's disease shows toxicity and decreased histone acetylation. Neuroreport. 2003;14(4):565-8.

[80] Jiang H, Poirier MA, Liang Y, Pei Z, Weiskittel CE, Smith WW, DeFranco DB, Ross CA. Depletion of CBP is directly linked with cellular toxicity caused by mutant huntingtin. Neurobiol Dis. 2006;23(3):543-51

[81] Chiu CT, Liu G, Leeds P, Chuang DM. Combined treatment with the mood stabilizers lithium and valproate produces multiple beneficial effects in transgenic mouse models of Huntington's disease. Neuropsychopharmacology. 2011;36(12):2406-21.

[82] Giralt A, Puigdellivol M, Carreton O, Paoletti P, Valero J, Parra-Damas A, Saura CA, Alberch J, Gines S. Long-term memory deficits in Huntington's disease are associated with reduced CBP histone acetylase activity. Hum Mol Genet. 2012;21(6):1203-16.

[83] Lim S, Chesser AS, Grima JC, Rappold PM, Blum D, Przedborski S, Tieu K. D-beta-hydroxybutyrate is protective in mouse models of Huntington's disease. PLoS One. 2011;6(9):e24620

[84] Stack EC, Del Signore SJ, Luthi-Carter R, Soh BY, Goldstein DR, Matson S, Goodrich S, Markey AL, Cormier K, Hagerty SW, Smith K, Ryu H, Ferrante RJ. Modulation of nucleosome dynamics in Huntington's disease. Hum Mol Genet. 2007;16(10):1164-75.

[85] Hockly E, Richon VM, Woodman B, Smith DL, Zhou X, Rosa E, Sathasivam K, Ghazi-Noori S, Mahal A, Lowden PA, Steffan JS, Marsh JL, Thompson LM, Lewis CM, Marks PA, Bates GP. Suberoylanilide hydroxamic acid, a histone deacetylase inhibitor, ameliorates motor deficits in a mouse model of Huntington's disease. Proc Natl Acad Sci U S A. 2003;100(4):2041-46.

[86] Klevytska AM, Tebbenkamp AT, Savonenko AV, Borchelt DR. Partial depletion of CREB-binding protein reduces life expectancy in a mouse model of Huntington disease. J Neuropathol Exp Neurol. 2010;69(4): 396-404.

[87] Oliveira JM, Chen S, Almeida S, Riley R, Goncalves J, Oliveira CR, Hayden MR, Nicholls DG, Ellerby LM, Rego AC. Mitochondrial-dependent $\mathrm{Ca} 2+$ handling in 
Huntington's disease striatal cells: Effect of histone deacetylase inhibitors. J Neurosci. 2006;26(43):11174-86.

[88] Sadri-Vakili G, Bouzou B, Benn CL, Kim MO, Chawla P, Overland RP, Glajch KE, Xia E, Qiu Z, Hersch SM, Clark TW, Yohrling GJ, Cha JH. Histones associated with downregulated genes are hypo-acetylated in Huntington's disease models. Hum Mol Genet. 2007;16(11): 1293-306.

[89] Valor LM, Viosca J, Lopez-Atalaya JP, Barco A. Lysine acetyltransferases CBP and p300 as therapeutic targets in cognitive and neurodegenerative disorders. Curr Pharm Des. 2013;19(28):5051-64

[90] Thomas EA, Coppola G, Desplats PA, Tang B, Soragni E, Burnett R, Gao F, Fitzgerald KM, Borok JF, Herman D, Geschwind DH, Gottesfeld JM. The HDAC inhibitor 4b ameliorates the disease phenotype and transcriptional abnormalities in Huntington's disease transgenic mice. Proc Natl Acad Sci U S A. 2008;105(40):15564-69.

[91] McFarland KN, Das S, Sun TT, Leyfer D, Xia E, Sangrey GR, Kuhn A, Luthi-Carter R, Clark TW, Sadri-Vakili G, Cha JH. Genome-wide histone acetylation is altered in a transgenic mouse model of Huntington's disease. PLoS One. 2012;7(7):e41423.

[92] Valor LM, Guiretti D, Lopez-Atalaya JP, Barco A. Genomic landscape of transcriptional and epigenetic dysregulation in early onset polyglutamine disease. J Neurosci. 2013;33(25):10471-82.

[93] Kazantsev A, Preisinger E, Dranovsky A, Goldgaber D, Housman D. Insoluble detergent-resistant aggregates form between pathological and nonpathological lengths of polyglutamine in mammalian cells. Proc Natl Acad Sci U S A. 1999;96(20):11404-09.

[94] Berke JD, Okatan M, Skurski J, Eichenbaum HB. Oscillatory entrainment of striatal neurons in freely moving rats. Neuron. 2004;43(6):883-96.

[95] McCampbell A, Taylor JP, Taye AA, Robitschek J, Li M, Walcott J, Merry D, Chai Y, Paulson H, Sobue G, Fischbeck KH. CREB-binding protein sequestration by expanded polyglutamine. Hum Mol Genet. 2000;9(14):2197-202.

[96] Taylor JP, Taye AA, Campbell C, Kazemi-Esfarjani P, Fischbeck KH, Min KT. Aberrant histone acetylation, altered transcription, and retinal degeneration in a Drosophila model of polyglutamine disease are rescued by CREBbinding protein. Genes Dev. 2003;17(12):1463-8.

[97] Yeh HH, Young D, Gelovani JG, Robinson A, Davidson Y, Herholz K, Mann DM. Histone deacetylase class II and acetylated core histone immunohistochemistry in human brains with Huntington's disease. Brain Res. 2013;1504:1624.

[98] Steffan JS, Bodai L, Pallos J, Poelman M, McCampbell A, Apostol BL, Kazantsev A, Schmidt E, Zhu YZ, Greenwald M, Kurokawa R, Housman DE, Jackson GR, Marsh JL, Thompson LM. Histone deacetylase inhibitors arrest polyglutamine-dependent neurodegeneration in Drosophila. Nature. 2001;413(6857):739-43.

[99] Obrietan K, Hoyt KR. CRE-mediated transcription is increased in Huntington's disease transgenic mice. J Neurosci. 2004;24(4):791-6.

[100] Tallaksen-Greene SJ, Crouse AB, Hunter JM, Detloff PJ, Albin RL. Neuronal intranuclear inclusions and neuropil aggregates in $\mathrm{HdhCAG}(150)$ knockin mice. Neuroscience. 2005;131(4):843-52.

[101] Yu ZX, Li SH, Nguyen HP, Li XJ. Huntingtin inclusions do not deplete polyglutamine-containing transcription factors in HD mice. Hum Mol Genet. 2002;11(8):905-14.
[102] Cong SY, Pepers BA, Evert BO, Rubinsztein DC, Roos RA, van Ommen GJ, Dorsman JC. Mutant huntingtin represses CBP, but not $\mathrm{p} 300$, by binding and protein degradation. Mol Cell Neurosci. 2005;30(4):560-71.

[103] Choi YJ, Kim SI, Lee JW, Kwon YS, Lee HJ, Kim SS, Chun W. Suppression of aggregate formation of mutant huntingtin potentiates CREB-binding protein sequestration and apoptotic cell death. Mol Cell Neurosci. 2012;49(2):127-37.

[104] Kita H, Carmichael J, Swartz J, Muro S, Wyttenbach A, Matsubara K, Rubinsztein DC, Kato K. Modulation of polyglutamine-induced cell death by genes identified by expression profiling. Hum Mol Genet. 2002;11(19):227987.

[105] Sipione S, Rigamonti D, Valenza M, Zuccato C, Conti L, Pritchard J, Kooperberg C, Olson JM, Cattaneo E. Early transcriptional profiles in huntingtin-inducible striatal cells by microarray analyses. Hum Mol Genet. 2002;11(17):195365.

[106] Jiang H, Nucifora FC, Jr., Ross CA, DeFranco DB. Cell death triggered by polyglutamine-expanded huntingtin in a neuronal cell line is associated with degradation of CREBbinding protein. Hum Mol Genet. 2003;12(1):1-12.

[107] Hoshino M, Tagawa K, Okuda T, Murata M, Oyanagi K, Arai N, Mizutani T, Kanazawa I, Wanker EE, Okazawa $\mathrm{H}$. Histone deacetylase activity is retained in primary neurons expressing mutant huntingtin protein. J Neurochem. 2003;87(1):257-67.

[108] Quinti L, Chopra V, Rotili D, Valente S, Amore A, Franci G, Meade S, Valenza M, Altucci L, Maxwell MM, Cattaneo E, Hersch S, Mai A, Kazantsev A. Evaluation of histone deacetylases as drug targets in Huntington's disease models. Study of HDACs in brain tissues from R6/2 and CAG140 knock-in HD mouse models and human patients and in a neuronal HD cell model. PLoS Curr. 2010;2:pii: RRN1172.

[109] Wu S, Zheng SD, Huang HL, Yan LC, Yin XF, Xu HN, Zhang KJ, Gui JH, Chu L, Liu XY. Lithium down-regulates histone deacetylase 1 (HDAC1) and induces degradation of mutant huntingtin. J Biol Chem. 2013;288(49):35500-10.

[110] Bardai FH, Verma P, Smith C, Rawat V, Wang L, D'Mello SR. Disassociation of histone deacetylase-3 from normal huntingtin underlies mutant huntingtin neurotoxicity. J Neurosci. 2013;33(29):11833-38.

[111] Bates EA, Victor M, Jones AK, Shi Y, Hart AC. Differential contributions of Caenorhabditis elegans histone deacetylases to huntingtin polyglutamine toxicity. J Neurosci. 2006;26(10):2830-38.

[112] Pallos J, Bodai L, Lukacsovich T, Purcell JM, Steffan JS, Thompson LM, Marsh JL. Inhibition of specific HDACs and sirtuins suppresses pathogenesis in a Drosophila model of Huntington's disease. Hum Mol Genet. 2008;17(23):376775.

[113] Benn CL, Butler R, Mariner L, Nixon J, Moffitt H, Mielcarek M, Woodman B, Bates GP. Genetic knock-down of HDAC7 does not ameliorate disease pathogenesis in the R6/2 mouse model of Huntington's disease. PLoS One. 2009;4(6): e5747.

[114] Bobrowska A, Donmez G, Weiss A, Guarente L, Bates G. SIRT2 ablation has no effect on tubulin acetylation in brain, cholesterol biosynthesis or the progression of Huntington's disease phenotypes in vivo. PLoS One. 2012;7(4): e34805.

[115] Bobrowska A, Paganetti P, Matthias P, Bates GP. Hdac6 knock-out increases tubulin acetylation but does not modify disease progression in the R6/2 mouse model of Huntington's disease. PLoS One. 2011;6(6):e20696. 
[116] Moumne L, Campbell K, Howland D, Ouyang Y, Bates GP. Genetic knock-down of HDAC3 does not modify diseaserelated phenotypes in a mouse model of Huntington's disease. PLoS One. 2012;7(2):e31080.

[117] Mielcarek M, Landles C, Weiss A, Bradaia A, Seredenina $\mathrm{T}$, Inuabasi L, Osborne GF, Wadel $\mathrm{K}$, Touller C, Butler R, Robertson J, Franklin SA, Smith DL, Park L, Marks PA, Wanker EE, Olson EN, Luthi-Carter R, van der Putten $\mathrm{H}$, Beaumont V, Bates GP. HDAC4 reduction: A novel therapeutic strategy to target cytoplasmic huntingtin and ameliorate neurodegeneration. PLoS Biol. 2013;11(11):e1001717.

[118] Ma C, D'Mello SR. Neuroprotection by histone deacetylase7 (HDAC7) occurs by inhibition of c-jun expression through a deacetylase-independent mechanism. J Biol Chem. 2011;286(6):4819-28.

[119] Rice JC, Allis CD. Histone methylation versus histone acetylation: New insights into epigenetic regulation. Curr Opin Cell Biol. 2001;13(3):263-73.

[120] Brami-Cherrier K, Roze E, Girault JA, Betuing S, Caboche $\mathrm{J}$. Role of the ERK/MSK1 signalling pathway in chromatin remodelling and brain responses to drugs of abuse. J Neurochem. 2009;108(6):1323-35.

[121] Bernstein BE, Humphrey EL, Erlich RL, Schneider R, Bouman P, Liu JS, Kouzarides T, Schreiber SL. Methylation of histone H3 Lys 4 in coding regions of active genes. Proc Natl Acad Sci U S A. 2002;99(13):8695-700.

[122] Kim TH, Barrera LO, Zheng M, Qu C, Singer MA, Richmond TA, Wu Y, Green RD, Ren B. A high-resolution map of active promoters in the human genome. Nature. 2005;436(7052):876-80.

[123] Santos-Rosa H, Schneider R, Bannister AJ, Sherriff J, Bernstein BE, Emre NC, Schreiber SL, Mellor J, Kouzarides T. Active genes are tri-methylated at $\mathrm{K} 4$ of histone $\mathrm{H} 3$. Nature. 2002;419(6905):407-11.

[124] Vashishtha M, Ng CW, Yildirim F, Gipson TA, Kratter IH, Bodai L, Song W, Lau A, Labadorf A, Vogel-Ciernia A, Troncosco J, Ross CA, Bates GP, Krainc D, Sadri-Vakili G, Finkbeiner S, Marsh JL, Housman DE, Fraenkel E, Thompson LM. Targeting H3K4 trimethylation in Huntington disease. Proc Natl Acad Sci U S A. 2013;110(32): E3027-36.

[125] Ferrante RJ, Ryu H, Kubilus JK, D’Mello S, Sugars KL, Lee J, Lu P, Smith K, Browne S, Beal MF, Kristal BS, Stavrovskaya IG, Hewett S, Rubinsztein DC, Langley B, Ratan RR. Chemotherapy for the brain: The antitumor antibiotic mithramycin prolongs survival in a mouse model of Huntington's disease. J Neurosci. 2004;24(46): 10335-42.

[126] Ryu H, Lee J, Hagerty SW, Soh BY, McAlpin SE, Cormier KA, Smith KM, Ferrante RJ. ESET/SETDB1 gene expression and histone $\mathrm{H} 3$ (K9) trimethylation in Huntington's disease. Proc Natl Acad Sci U S A. 2006;103(50): 19176-81.

[127] Qiu Z, Norflus F, Singh B, Swindell MK, Buzescu R, Bejarano M, Chopra R, Zucker B, Benn CL, DiRocco DP, Cha JH, Ferrante RJ, Hersch SM. Sp1 is up-regulated in cellular and transgenic models of Huntington disease, and its reduction is neuroprotective. J Biol Chem. 2006;281(24):16672-80.

[128] Chen-Plotkin AS, Sadri-Vakili G, Yohrling GJ, Braveman MW, Benn CL, Glajch KE, DiRocco DP, Farrell LA, Krainc D, Gines S, MacDonald ME, Cha JH. Decreased association of the transcription factor Sp1 with genes downregulated in Huntington's disease. Neurobiol Dis. 2006;22(2):233-41.
[129] Li SH, Cheng AL, Zhou H, Lam S, Rao M, Li H, Li XJ. Interaction of Huntington disease protein with transcriptional activator Sp1. Mol Cell Biol. 2002;22(5):1277-87.

[130] Eustermann S, Yang JC, Law MJ, Amos R, Chapman LM, Jelinska C, Garrick D, Clynes D, Gibbons RJ, Rhodes D, Higgs DR, Neuhaus D. Combinatorial readout of histone H3 modifications specifies localization of ATRX to heterochromatin. Nat Struct Mol Biol. 2011;18(7):777-82.

[131] Iwase S, Xiang B, Ghosh S, Ren T, Lewis PW, Cochrane JC, Allis CD, Picketts DJ, Patel DJ, Li H, Shi Y. ATRX ADD domain links an atypical histone methylation recognition mechanism to human mental-retardation syndrome. Nat Struct Mol Biol. 2011;18(7):769-76.

[132] Lee J, Hong YK, Jeon GS, Hwang YJ, Kim KY, Seong KH, Jung MK, Picketts DJ, Kowall NW, Cho KS, Ryu H. ATRX induction by mutant huntingtin via $\mathrm{Cdx} 2$ modulates heterochromatin condensation and pathology in Huntington's disease. Cell Death Differ. 2012;19(7):1109-16.

[133] Yazawa I, Hazeki N, Nakase H, Kanazawa I, Tanaka M. Histone $\mathrm{H} 3$ is aberrantly phosphorylated in glutaminerepeat diseases. Biochem Biophys Res Commun. 2003;302(1):144-9.

[134] Roze E, Betuing S, Deyts C, Marcon E, Brami-Cherrier K, Pages C, Humbert S, Merienne K, Caboche J. Mitogen- and stress-activated protein kinase-1 deficiency is involved in expanded-huntingtin-induced transcriptional dysregulation and striatal death. FASEB J. 2008;22(4):1083-93.

[135] Crosio C, Heitz E, Allis CD, Borrelli E, Sassone-Corsi P. Chromatin remodeling and neuronal response: Multiple signaling pathways induce specific histone $\mathrm{H} 3$ modifications and early gene expression in hippocampal neurons. J Cell Sci. 2003;116(Pt 24):4905-14.

[136] Sng JC, Taniura H, Yoneda Y. Histone modifications in kainate-induced status epilepticus. Eur J Neurosci. 2006;23(5):1269-82.

[137] Tsankova NM, Kumar A, Nestler EJ. Histone modifications at gene promoter regions in rat hippocampus after acute and chronic electroconvulsive seizures. J Neurosci. 2004:24(24):5603-10.

[138] Martin E, Betuing S, Pages C, Cambon K, Auregan G, Deglon N, Roze E, Caboche J. Mitogen- and stress-activated protein kinase 1-induced neuroprotection in Huntington's disease: Role on chromatin remodeling at the PGC-1-alpha promoter. Hum Mol Genet. 2011;20(12):2422-34.

[139] Giuliano P, De Cristofaro T, Affaitati A, Pizzulo GM, Feliciello A, Criscuolo C, De Michele G, Filla A, Avvedimento $\mathrm{EV}$, Varrone S. DNA damage induced by polyglutamineexpanded proteins. Hum Mol Genet. 2003;12(18):2301-09.

[140] Illuzzi J, Yerkes S, Parekh-Olmedo H, Kmiec EB. DNA breakage and induction of DNA damage response proteins precede the appearance of visible mutant huntingtin aggregates. J Neurosci Res. 2009;87(3):733-47.

[141] Jeon GS, Kim KY, Hwang YJ, Jung MK, An S, Ouchi M, Ouchi T, Kowall N, Lee J, Ryu H. Deregulation of BRCA1 leads to impaired spatiotemporal dynamics of gamma$\mathrm{H} 2 \mathrm{AX}$ and DNA damage responses in Huntington's disease. Mol Neurobiol. 2012;45(3):550-63.

[142] Bonisch C, Hake SB. Histone H2A variants in nucleosomes and chromatin: More or less stable? Nucleic Acids Res. 2012;40(21):10719-41.

[143] Lu XH, Mattis VB, Wang N, Al-Ramahi I, van den Berg $\mathrm{N}$, Fratantoni SA, Waldvogel H, Greiner E, Osmand A, Elzein K, Xiao J, Dijkstra S, de Pril R, Vinters HV, Faull R, Signer E, Kwak S, Marugan JJ, Botas J, Fischer DF, Svendsen CN, Munoz-Sanjuan I, Yang XW. Targeting 
ATM ameliorates mutant Huntingtin toxicity in cell and animal models of Huntington's disease. Sci Transl Med. 2014;6(268):268ra178.

[144] Braun S, Madhani HD. Shaping the landscape: Mechanistic consequences of ubiquitin modification of chromatin EMBO Rep. 2012;13(7):619-30.

[145] Bett JS, Benn CL, Ryu KY, Kopito RR, Bates GP. The polyubiquitin Ubc gene modulates histone $\mathrm{H} 2 \mathrm{~A}$ monoubiquitylation in the R6/2 mouse model of Huntington's disease. J Cell Mol Med. 2009;13(8B):2645-57.

[146] Kim MO, Chawla P, Overland RP, Xia E, Sadri-Vakili G, Cha JH. Altered histone monoubiquitylation mediated by mutant huntingtin induces transcriptional dysregulation. J Neurosci. 2008;28(15):3947-57.

[147] McFarland KN, Das S, Sun TT, Leyfer D, Kim MO, Xia E, Sangrey GR, Kuhn A, Luthi-Carter R, Clark TW, SadriVakili G, Cha JH. Genome-wide increase in histone H2A ubiquitylation in a mouse model of Huntington's disease. J Huntingtons Dis. 2013;2(3):263-77.

[148] Biagioli M, Ferrari F, Mendenhall EM, Zhang Y, Erdin S, Vijayvargia R, Vallabh SM, Solomos N, Manavalan P, Ragavendran A. Htt CAG repeat expansion confers pleiotropic gains of mutant huntingtin function in chromatin regulation. Hum Mol Genet. 2015: pii: ddv006. doi: 10.1093/hmg/ddv006

[149] McCampbell A, Taye AA, Whitty L, Penney E, Steffan JS, Fischbeck KH. Histone deacetylase inhibitors reduce polyglutamine toxicity. Proc Natl Acad Sci U S A. 2001;98(26):15179-84.

[150] Lee J, Hwang YJ, Kim KY, Kowall NW, Ryu H. Epigenetic mechanisms of neurodegeneration in Huntington's disease. Neurotherapeutics. 2013;10(4):664-76.

[151] Jia H, Morris CD, Williams RM, Loring JF, Thomas EA. HDAC inhibition imparts beneficial transgenerational effects in Huntington's disease mice via altered DNA and histone methylation. Proc Natl Acad Sci U S A. 2015;112(1):E56-64.

[152] Thomas EA. Focal nature of neurological disorders necessitates isotype-selective histone deacetylase (HDAC) inhibitors. Mol Neurobiol. 2009;40(1):33-45.

[153] Thomas EA. Involvement of HDAC1 and HDAC3 in the pathology of polyglutamine disorders: Therapeutic implications for selective HDAC1/HDAC3 inhibitors. Pharmaceuticals (Basel). 2014;7(6):634-61.

[154] Xu WS, Parmigiani RB, Marks PA. Histone deacetylase inhibitors: Molecular mechanisms of action. Oncogene. 2007;26(37):5541-52.

[155] Jia H, Kast RJ, Steffan JS, Thomas EA. Selective histone deacetylase (HDAC) inhibition imparts beneficial effects in Huntington's disease mice: Implications for the ubiquitinproteasomal and autophagy systems. Hum Mol Genet. 2012;21(24):5280-93

[156] Jia H, Pallos J, Jacques V, Lau A, Tang B, Cooper A, Syed A, Purcell J, Chen Y, Sharma S, Sangrey GR, Darnell SB, Plasterer H, Sadri-Vakili G, Gottesfeld JM, Thompson LM, Rusche JR, Marsh JL, Thomas EA. Histone deacetylase (HDAC) inhibitors targeting HDAC3 and HDAC1 amelio- rate polyglutamine-elicited phenotypes in model systems of Huntington's disease. Neurobiol Dis. 2012;46(2):351-61.

[157] Beconi M, Aziz O, Matthews K, Moumne L, O'Connell C, Yates D, Clifton S, Pett H, Vann J, Crowley L, Haughan AF, Smith DL, Woodman B, Bates GP, Brookfield F, Burli RW, McAllister G, Dominguez C, Munoz-Sanjuan I, Beaumont V. Oral administration of the pimelic diphenylamide HDAC inhibitor HDACi $4 \mathrm{~b}$ is unsuitable for chronic inhibition of HDAC activity in the CNS in vivo. PLoS One. 2012;7(9):e44498.

[158] Burli RW, Luckhurst CA, Aziz O, Matthews KL, Yates D, Lyons KA, Beconi M, McAllister G, Breccia P, Stott AJ, Penrose SD, Wall M, Lamers M, Leonard P, Muller I, Richardson CM, Jarvis R, Stones L, Hughes S, Wishart G, Haughan AF, O'Connell C, Mead T, McNeil H, Vann J, Mangette J, Maillard M, Beaumont V, Munoz-Sanjuan I, Dominguez C. Design, synthesis, and biological evaluation of potent and selective class IIa histone deacetylase (HDAC) inhibitors as a potential therapy for Huntington's disease. J Med Chem. 2013;56(24):9934-54.

[159] Lopez-Atalaya JP, Ito S, Valor LM, Benito E, Barco A. Genomic targets, and histone acetylation and gene expression profiling of neural HDAC inhibition. Nucleic Acids Res. 2013;41(17):8072-84.

[160] Lundby A, Lage K, Weinert BT, Bekker-Jensen DB, Secher A, Skovgaard T, Kelstrup CD, Dmytriyev A, Choudhary C, Lundby C, Olsen JV. Proteomic analysis of lysine acetylation sites in rat tissues reveals organ specificity and subcellular patterns. Cell Rep. 2012;2(2):419-31.

[161] Choudhary C, Kumar C, Gnad F, Nielsen ML, Rehman M, Walther TC, Olsen JV, Mann M. Lysine acetylation targets protein complexes and co-regulates major cellular functions. Science. 2009;325(5942):834-40.

[162] Jeong H, Then F, Melia TJ, Jr., Mazzulli JR, Cui L, Savas JN, Voisine C, Paganetti P, Tanese N, Hart AC, Yamamoto A, Krainc D. Acetylation targets mutant huntingtin to autophagosomes for degradation. Cell. 2009;137(1): 60-72.

[163] Thompson LM, Aiken CT, Kaltenbach LS, Agrawal N, Illes K, Khoshnan A, Martinez-Vincente M, Arrasate M, O'Rourke JG, Khashwji H, Lukacsovich T, Zhu YZ, Lau AL, Massey A, Hayden MR, Zeitlin SO, Finkbeiner S, Green KN, LaFerla FM, Bates G, Huang L, Patterson PH, Lo DC, Cuervo AM, Marsh JL, Steffan JS. IKK phosphorylates Huntingtin and targets it for degradation by the proteasome and lysosome. J Cell Biol. 2009;187(7):1083-99.

[164] Dompierre JP, Godin JD, Charrin BC, Cordelieres FP, King SJ, Humbert S, Saudou F. Histone deacetylase 6 inhibition compensates for the transport deficit in Huntington's disease by increasing tubulin acetylation. J Neurosci. 2007;27(13):3571-83.

[165] Cattaneo E, Zuccato C, Tartari M. Normal huntingtin function: An alternative approach to Huntington's disease. Nat Rev Neurosci. 2005;6(12):919-30.

[166] Piekarski M, Jelinska A. Anthracyclines still prove effective in anticancer therapy. Mini Rev Med Chem. 2013;13(5):627-34. 